\title{
MacLaran A. (éd.) Making space, property development and urban planning
}

London, Arnold, $259 \mathrm{p}$.

\section{J. Vandeburie}

\section{CpenEdition}

Journals

Electronic version

URL: http://journals.openedition.org/belgeo/13464

ISSN: 2294-9135

\section{Publisher:}

National Committee of Geography of Belgium, Société Royale Belge de Géographie

Printed version

Date of publication: 31 December 2004

Number of pages: 497-508

ISSN: 1377-2368

\section{Electronic reference}

J. Vandeburie, " MacLaran A. (éd.) Making space, property development and urban planning », Belgeo [Online], 4 | 2004, Online since 15 September 2013, connection on 22 September 2020. URL : http:// journals.openedition.org/belgeo/13464

This text was automatically generated on 22 September 2020.

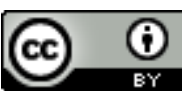

Belgeo est mis à disposition selon les termes de la licence Creative Commons Attribution 4.0 International. 
MacLaran A. (éd.) Making space, property development and urban planning

London, Arnold, 259 p.

J. Vandeburie 


\section{REFERENCES}

MacLaran A. (éd.), Making space, property development and urban planning, London, Arnold, 2003, 259 p.

1 «This book is about building cities. It focuses on the private-sector forces responsible for their development and the arrangements put in place to guide, manipulate and control them. " According to the author, the public sector plays a direct role in the development of the urban space, by building for example transport infrastructures and too risky elements for the private sector. But the predominant focus of this book is about private-sector development « industry ».

2 After the introduction, MacLaran develops how the property development sector are masters of space with a lot of examples and examines the question of the driving force : profit. The third chapter is about the ways of planning the city. MacLaran and MacGuirck discuss the activity of urban planning and planning ideologies.

3 In a second part, the book focuses on some case studies. First is Minneapolis' rejuvenation. The role of private-sector interests is shown. Then, the case of central Sydney. Thirdly the case of Dublin in its particular context. Fourthly Auckland, New Zealand ; sixthly Birmingham and finally the contradictions of Sioux Falls.

4 Finally, a good book for examples of private-sector planning in cities, with pictures and maps of excellent quality and a good bibliography. We can regret the lack of any examples of Latin cities, from Europe to Latin America, or even Asian or African cities. 